\title{
COMMENT
}

\section{Ayurveda for comprehensive healthcare}

\author{
SANJEEV RASTOGI
}

Department of Kaya Chikitsa, State Ayurvedic College and Hospital, Tulsi Das Marg, Lucknow 226004 INDIA email: rastogisanjeev@rediffmail.com

In the 1950s, the World Health Organisation, the apex organisation for global health, defined health as "a state of complete physical, mental and social well being and not merely the absence of disease or infirmity" (1).

Indeed, there is considerable evidence, including in modern western medicine, to suggest a strong link between physical and psychological aspects of health and disease. Physical symptoms sometimes have psychological origins (2). The mental and physical aspects of health are complexly intertwined not only as a subject of study in medicine but also in our daily lives.

Following the WHO definition, health can be defined as an outcome of multiple factors operating at various levels. Good health permits the optimal utilisation of one's physical and mental abilities for one's own good as well as for society. This means that health cannot be tackled as an isolated subject of action; there are so many factors affecting it-from socioeconomic determinants to gender, caste, regional and other inequalities-and these must be addressed if one is to improve people's health.

Today, this definition of health is being challenged as utopian and there is a move to develop what is described as a more practical and workable definition that focuses on certain "key indicators" $(3,4,5)$

\section{The original healthcare model in India and where we are today}

The ideas expressed by the WHO in the 1970s were recognised decades earlier, at the time that India was developing its health system. The health care model adopted by India after Independence is based on the recommendations of various committees commissioned to shape the country's healthcare system. These committees called for an integration of various components of healthcare.

As early as in 1946, the Bhore Committee called for a social orientation of medical practice with public participation, an emphasis on preventive medicine and the consequent development of environmental health (6). It envisioned the doctor of the future as a social doctor who could combine curative and preventive measures. Bhore was speaking of the socialisation of medicine through primary health care long before it was conceived by the WHO and expressed in its Alma Ata declaration.
Despite the holistic views expressed at the time health policies and programmes were being developed, India's healthcare policy has largely remained a curative policy with a secondary emphasis on prevention and on the socioeconomic issues that affect health outcomes. The health system's focus on cure resulted in the development of high technology, cost-intensive procedures in both the private and the public sectors. Needless to say, this has ensured that the healthcare system is a profitmaking industry that is meant for the use of the rich and inaccessible to the underprivileged.

More than six decades have gone by since the Bhore committee's recommendations. A look back over these decades also allows us evaluate the successes and failures of the policy.

The results are described in the mission statement of the National Rural Health Mission (NRHM) in 2005. It highlights various regional inequalities, the lack of integration of sanitation, hygiene, nutrition and safe drinking water into health plans, and the lack of efficiency, accountability and effectiveness in existing programmes (7). It also notes that curative services favour the better-off. The average Indian is often forced to borrow money in order to pay for health care. The states with the largest share of the population have the worst healthcare systems.

However three years after the launch of the NRHM, we are far from the targets it set for 2012. For example, three years after its introduction in Uttar Pradesh in 2006, and with an investment of over Rs 3,000 crore, health standards in the state have not improved substantially. The infant mortality rate, the maternal mortality ratio, vaccination coverage and percentage of institutional delivery were a few key health indicators where the NRHM was supposed to concentrate, with targets fixed for 2012. Nearly halfway through the NRHM's term, the only standard that has improved is the percentage of institutional deliveries (6).

India is blessed with capable doctors. It also has human resources involved in the form of consultants and paramedics. Apart from state-owned services, private institutions provide healthcare to our country. There is no shortage of money: the various health care programmes do not face funding problems. We have the skills, the infrastructure and the money.

However, despite these infrastructural strengths and the financial support, the modern health care system has failed to reach people and provide healthcare services to the needy. 
We require a system of effective health care delivery to optimally utilise available resources for our own people, and that enables them to enjoy the all-encompassing definition of health described by the WHO.

The diversity in almost every domain and throughout the country argues for a flexible planning approach suited to various needs. There are substantial regional, social, economic and gender inequalities affecting access to education, work and healthcare and therefore health. While India faces an epidemic of metabolic, cardiovascular, degenerative and other non-communicable illnesses, communicable diseases still are major causes for morbidity and mortality. We also need to care about the physical and mental impact of industrialisation and globalisation. Any expenditure in health should be considered an investment and not expenditure.

\section{An integrated definition of health}

It is interesting that the WHO's integrated definition of health was actually articulated 2,000 years ago. Sushruta defined health as a physiological balance added to a psycho-sensual happiness (8). The mere absence of disease in a person does not bring happiness. Better health is expressed not in terms of a longer life but in terms of a better quality of life. Health has socioeconomic determinants. Curative practices must be accompanied by preventive measures.

Sushruta goes further: health is also affected by one's moral, social and spiritual values. Ayurveda holds that Dharma (spiritual gains), Artha (monetary gains), Kama (sensual gains) and Moksha (liberation), the four primary objectives of human life, are possible only for a healthy human being.

Healthy people are prerequisite to optimise human resource utilisation. An ideal health care system as defined by Ayurveda is one which cures a disease without causing or precipitating other illness (Shamyet yo na kopyet) (9).

We all know about the benefits of preventive medicine. Thousands of years ago, Ayurveda pointed out the importance of a preventive over a curative approach, because it has an impact for many generations.

Ayurveda also had views on how individuals should be involved in their own health and health care. The cultivation of health becomes the responsibility of the individual, not of the institution. Means of promoting preventive health should involve the people not merely as passive recipients of plans but also as the active controllers of their own health by utilisation of the resources available to them. The state's responsibility is to make them aware of the ways of achieving good health-encompassing the role of a coordinator, motivator and facilitator, not just merely the sole custodian of preventive health for the people.

Systems such as Ayurveda, unani, siddha, yoga and nature cure have been practised for centuries and their impact upon health is well known (10).They are incorporated in household remedies. They are also used extensively where state health care services are not available or affordable.

Every healthcare system has its limitations and advantages. There are conditions where some or the other system may work better than the other, if tried early in the course of illness.

The modern system of medicine forms the basis of the health care infrastructure in India with a majority of the budget allocated to it. Unfortunately this neglects the holistic approach to medicine. Further, it has failed to make a substantial difference to people's health.

Very little concrete action has been taken to incorporate other systems of medicine into the health care system and to support them. For example, an observation of Ayurvedic hospitals presents a pathetic picture of their status. Ayurvedic hospitals in Uttar Pradesh have less than one per cent hospital occupancy ratio and no one has seriously considered why this is the case.

NRHM makes a progressive move by looking to mainstream AYUSH (Ayurveda, Yoga, Unani, Siddha and Homoeopathy) and bring their advantages to millions. Ayurveda has been identified for a few practices like Pancha Karma and Kshar Sutra therapy which are supposed to be beneficial for neuromuscular and ano-rectal diseases respectively.

\section{Conclusion}

Healthcare in India should operate on a need based strategy. This should evaluate the utility of advancements in health care but simultaneously taking care for not devaluing the essentials of traditional healthcare fundamentals. A serious effort is required to improve healthcare by utilisation of traditional skills added with the technological breakthrough made in modern science.

\section{References}

1. World Health Organization. Basic documents. 39th ed. Geneva: WHO, 1992.

2. Fox K R. The influence of physical activity on mental well-being. Public Health Nutr 1999 Sep; 2(3a): 411-8.

3. Doll R. Health and the environment in the 1990s. Am J Public Health 1992 Jul; 82(7):933-41.

4. Ustun BT, Jakob R. Calling a spade a spade: meaningful definitions of health conditions. Bull World Health Organ 2005 Nov; 83 (11): 802-3.

5. Jadad AR, O'Grady L. How should health be defined? BMJ 2008; 337: a2900.

6. Goel S.From Bhore Committee to National Rural Health Mission:a critical review. The Internet Journal of Health 2008; 7(1). [journal on the internet]. [cited 2009 Mar 14]. Available from: http://www.ispub.com/journal/the internet_journal_of_health/volume_7_number_1_5/article_printable/ from_bhore_committee_to_national_rural_health_mission_a_critical_ review.html

7. Ministry of health and family welfare, government of India. National Rural Health Mission. [homepage on the internet]. [cited 2009 Mar 14]. Available from: http://mohfw.nic.in/nrhm.htm.

8. Shashtri AD, editor. Sushruta samhita. Varanasi: Chaukambha Sanskrit Sansthan; 2007.

9. Tripathi BN editor. Charaka samhita, Nidana sthana 8/23. Varanasi: Chaukhambha Surbharti Prakashana; 1983.

10. Rastogi S, Chandra Hem, Rastogi R. Practice of the Ayurvedic system of medicine: a pilot study. NAMAH 2008 Jan; 15(4): 19-38. 